\title{
特集／泌尿器科とレーザー
}

\section{側射用ファイバーを用いた前立腺レーザ一手術 Transurethral laser surgery of prostate using lateral firing fiber}

\author{
青木 豊, 野垣讓二, 岡田清己 \\ 日本大学医学部泌尿器科学教室
}

\author{
Yutaka AOKI, Joji NOGAKI and Kiyoki OKADA \\ Department of Urology, Nihon University School of Medicine \\ 30-1 Oyaguchikamimachi, Itabashi-ku, Tokyo 173
}

\begin{abstract}
要 旨
前立腺肥大症32症例に対し経尿道的前立腺レーザー手街（TULS-P）を行い，その効果を 評価した。適応は AUA 前立腺症状スコア（AUA-PSS）15点以上, 尿流測定にて最大尿流 率 $15 \mathrm{ml} / \mathrm{sec}$ 以下, 経直腸的超音波断層にて前立腺容量 $20 \mathrm{ml}$ 以上とした。レーザー照射は Nd：YAGレーザーを，ファイバーは LaserSonics 社製UltraLine ${ }^{\top M} を$ 用いた。照射方法は， Contact 照射により膀胱頸部から精阜にかけて 2 時・ 4 時・ 8 時・10時の 4 ケ所を基本部位 とし， 3 時・ 5 時・ 7 時・9 時に追加照射を行った。出力は50ワット，SPOT 照射または RUNNING 照射で30秒から60秒間の連続照射で行った。治療効果はAUA-PSS.・最大尿流率 - 残尿量・前立腺容積により判定した。各有効率は, AUA-PSS 81.3\%, 最大尿流率75.0\%, 残尿量 $87.5 \%$ ，前立腺容積 $96.9 \%$ であった。副作用としては，10例に一過性尿閉を，2例に急 性精策上体炎を認めた。以上より, 侧射用ファイバーを用いた前立腺レーザー手術は前立腺肥 大症の手術の一手段になり得るものと思われた。

キーワード：前立腺肥大症，レーザー手術，Nd：YAG，SPOT 照射，RUNNING 照射
\end{abstract}

\begin{abstract}
Thirty-two patients with BPH underwent transurethral laser surgery of prostate (TULS-P). In the present study the patients were selected according to the following criterion: above 15 points in AUA Prostate Symptom Score (AUA-PSS), bolew 15 $\mathrm{ml} / \mathrm{sec}$ in peak flow rate (uroflometry) and above $20 \mathrm{ml}$ prostate volume(transrectal ultrasound). Nd : YAG laser and UltraLine ${ }^{\mathrm{rM}}$ (LaserSonics) fiber were used during laser irradiation. The laser was irradiated at four radial regions $(2,4,8$ and 10 o'clock positions), additionally to $3,5,7$ and $90^{\prime}$ clock position, with the fiber being dragged from the bladder neck to verumontanum. The laser was set at 50 watts power on continuous wave. The irradiation was for 30 to 60 seconds and with spot and/or running irradiation. Clinical efficiency was determined by AUA-PSS, peak flow rate, residual urine, prostatic volume and side effect.

The effective rate were as follows, AUA-PSS; $81.3 \%$, peak flow rate ; $75.0 \%$,
\end{abstract}


residual urine ; $87.5 \%$ and prostatic volume ; $96.9 \%$. As to the side effect, 10 patients revealed urinary retention and two patients showed acute epididymitis after the operation. From the president study, TULS-P using lateral firing fiber would be one of the useful tool for the treatment of $\mathrm{BPH}$.

Key Words : BPH, laser surgery, Nd: YAG, spot irradiation, running irradiation

\section{I .はじめに}

前立腺肥大症は高龄者に多い疾患のため合併症を有し， 全身状態不良の例が多い。近年，高齢者の社会的活動能 力の向上と意識の变化に伴い，排泿障害の治療法につい て様々な研究がなされている。

前立腺肥大症の治療は観血的治療之非観血的治療に分 類される。観血的治療には手術に上る被膜下前立腺摘除 術か，内視鏡下で前立腺を切除する経尿道的前立腺切除 術（TUR-P）が行わ机てきた。TUR-Pは開㓣操作を 行わないため，入院期間も短く，術後排尿状態の改善も 比較的早くから認められるため，本邦においても広く受 け入れられている手術術式である。しかし，TUR-Pは 高度な技術が必要之さ机る上，個体差も大きいため，安 定した手術が行えるようになるには，ある程度の経験が 必要となる。その上, 出血, 第孔、TUR 症候群などの 術中の合併症, 術後の後出血の問題など比較的りスクが 高いといえる。

一方, 非観血的治療法として薬剤療法のほかに，温熱 療法 (1) ${ }^{21}$ ， バルーン拡張術 ${ }^{32}$ ，尿道ステントカテーテル 留㯰術》などが実施されるようになった。さらに新しい 試みとして TUR-P の技術を応用したレーザーによる 前立腺手術は出血が少なく，安全性も高いため注目さ㧈 るようになってきた。今回われわれは当教室で行われた 前立腺肥大症に対するレーザー前立腺手術の有効性につ いての検討を行った。

\section{II. 前立腺レーザー手術法}

\section{1. 対 象}

当教室では平成 5 年 1 月より動物実験が実施され，実 験結果を踏まえて臨床的に前立腺レーザー手術を開始し た。玩在 50 例の前立腺肥大症に対する TULS - P

(Transurethral Laser Surgery of Prostate) を経 呀したが，評価可能例は年齢53〜84歳（平均69.7歳）の 32例であった。これに基づき有効性及び安全性について の記載する。まず対象の条件として，a）排尿障害を訴 える者, b) AUA Prostate Symptom Score（以下 AUA-PSS）15点以上, c) 最大尿流率 $15 \mathrm{ml} / \mathrm{sec}$ 以下, d ）前立腺の大きさが值腸内触診にて小鶂卵大以上，あ るいは超音波断層像にて前立腺推定容積 $20 \mathrm{~m}$ 以上亡し た。尚, 50歳未満, 神経因性膀胱の患者, 膀胱機能へ影 響のある薬物を服用中の患者，前立腺癌の患者らは除外 対象とした。

\section{2. 照射方法}

麻酔は全例腰椎麻酔で行う。使用機器は尊光路として LaserSonics 社製UltraLine ${ }^{\top M}(600 \mu \mathrm{m}$ 径の側射ファ イバー）を用い，Nd：YAGレーザー発生装置よして は LaserSonics 社製 Model 6000

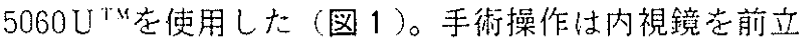
腺部尿道まで進め，ファイバーをプロープ用チャンネル から㨂入する。He-Ne レーザーがパイロットビームと して照射部位を示し、この部位を TVモニターで確認し ながら、Nd：YAGレーザーで前立腺を照射する。手 術操作は,ファイバ一先端の泠却及び良好な視野確保の ため海流液中で行われている。照射部位は膀胱頸部から 精皁までの放射状の 2 時・4 時・ 8 時・10時を基本的 4 部位とし，必要に応じて 3 時・9 時・ 5 時・7時を追加 照射する。照射方法としてプローブを固定したSPOT 照射之膀胱頸部から精阜までプローブを移動させながら 照射するRUNNING 照射を用いた（図 2，3）。 SPOT 照射は狭い範囲で蒸散が深く，周囲の凝固や術 後の浮腫が少ない。RUNNIN G照射は広い範囲で浅い

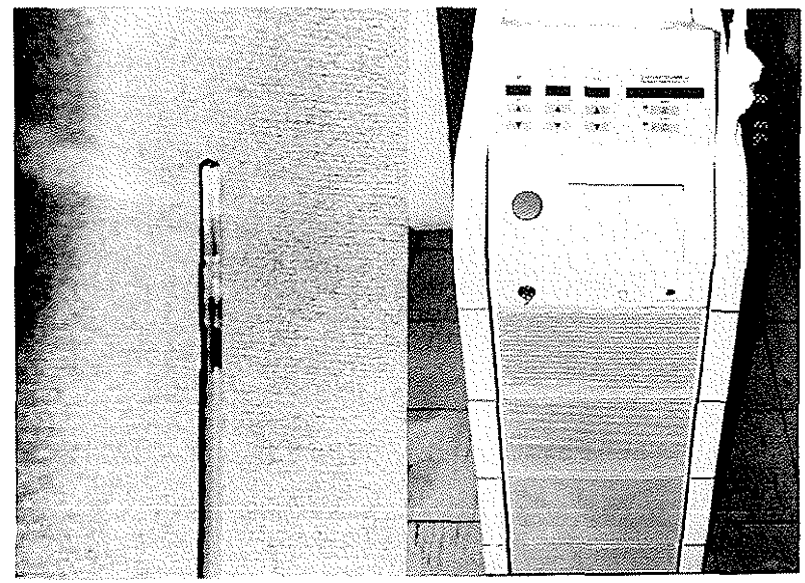

图 1 UltraLine \& Hercules5060U 


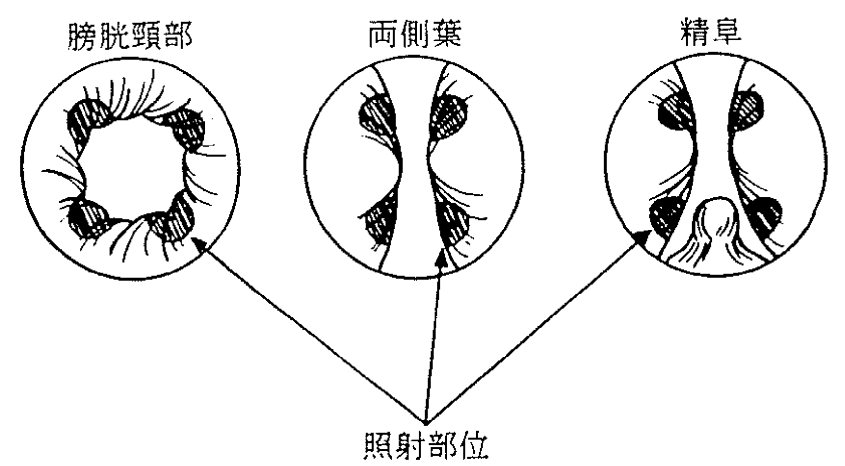

図 2 SPOT照射

蒸散が起こり，周囲の凝固が多く、術後浮腫も著名とな る。

\section{3. 効果判定法}

臨休効果の判定は, 術前书よび術後 8 週に行った。判 定項目は a ) AUA-PSS, b ) 最大尿流率（膀胱内に $200 \mathrm{ml}$ 以上の尿の貯留下で尿流測定施行)，c）残尿量,

d）前立腺推定容積（経直腸的超音波断層装置）を用い ている。効果は, a ) AUA-PSSの50\%以上の改善， b ) 最大尿流率の $50 \%$ 以上の改善，c）残尿量 $10 \mathrm{ml}$ 以下, d) 前立腺推定容積の $25 \%$ 以上の改善, のいずれかが見 られた時TULS-Pが奏功したよ判定した。

\section{III. 結 果}

前立腺肥大症患者 50 例中, 術後 8 週経過した時点で評 価可能例は年龄53〜84藏（平均69.7藏）の32例であった。 照射条件亡して出力は全例50ワットで行い，総照射量は 5900〜117, 030シュール（平均40,726ジュール）であっ た。総照射量が多かった症例は，前立腺が大きい場合之 移動照射のみ行った場合であった。手術時間は15〜125 分 (平均53.8分) であったが，長時間を要した症例は術 中に照射部位の梯子在確認し内視鏡撮影学行ったことな どによるものであり，手術そのものに費やされた時間は 約30分程度と考元ら机る。カテーテル留置期間は $3 \sim 14$ 日（平均7.8日）であったが，この中にカテーテルを再 留㯰した期間も含ま机ている。

術前の AUA-PSS は15〜33点 (平均21点) であり， 術後 8 週においては 2 27点（平均9.0点）であった。 AUA - PSS の50\%以上の改善は26例（81.3\%）に認め ら机た。

術前の最大尿流率は $0 \sim 14.4 \mathrm{ml} / \mathrm{sec}$ (平均 5.4 $\mathrm{ml} / \mathrm{sec)}$ であり, 徒後 8 週においては5.8〜29ml/

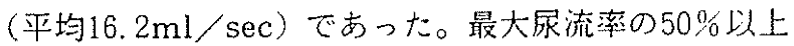
の改善は24例 $(75.0 \%)$ に認められた。

術前の残尿量は $15 〜 350 \mathrm{ml}$ (平均 $80.2 \mathrm{ml}$ ) なのに対 し, 術後 8 週では $0 \sim 40 \mathrm{ml}$ (平均 $8.5 \mathrm{ml}$ ) となり，そ

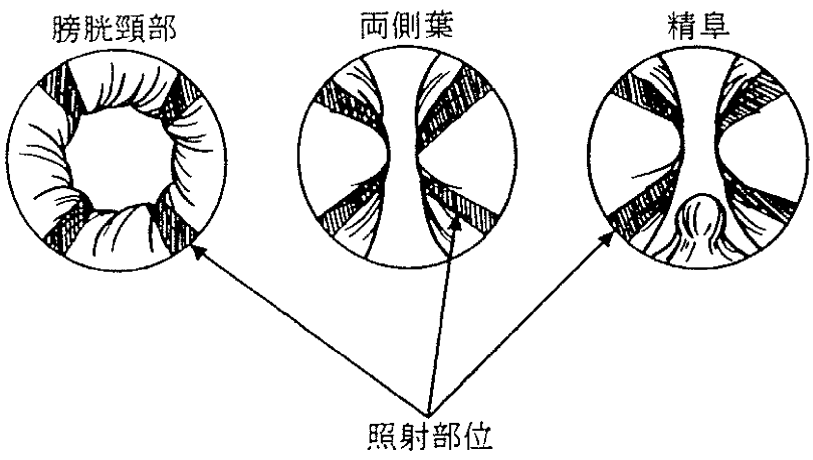

図 3 RUNNING照射

表 1 臨床結果（術前・術後 8 週） 数值は平均土標準偏差である

$(\mathrm{N}: 32)$

\begin{tabular}{|c||c|c|}
\hline & 術前 & 術後 8 週後 \\
\hline $\begin{array}{c}\text { AUA P.S.S. } \\
\text { (点) }\end{array}$ & $21 \pm 5.6$ & $9 \pm 5.7$ \\
\hline $\begin{array}{c}\text { 最大尿流率 } \\
(\mathrm{ml} / \mathrm{sec})\end{array}$ & $5.4 \pm 3.4$ & $16.2 \pm 4.8$ \\
\hline $\begin{array}{c}\text { 残尿率 } \\
(\mathrm{ml})\end{array}$ & $80.2 \pm 86.1$ & $8.5 \pm 11.9$ \\
\hline $\begin{array}{c}\text { 前立腺推定容皘 } \\
(\mathrm{ml})\end{array}$ & $29.6 \pm 8.5$ & $19.4 \pm 5.4$ \\
\hline
\end{tabular}

のうち10ml以下は28例（87.5\%）であった。

術前の前立腺推定容積は20.2 $55.0 \mathrm{ml}$ (平均 $29.6 \mathrm{ml}$ ) であったが、術後 8 週では11.3〜32. 3ml(平均 $19.4 \mathrm{ml}$ ) となった。前立腺推定容積の $25 \%$ 以上の改善は31例( 96.9 \%)であった。表 1 に術前および術後 8 週の結果をまと めた。

治療効果はAUA-PSS $81.3 \%$ ，最大尿流率 $75 \%$ ，残 尿量 $87.5 \%$ ，前立腺推定容積96. $9 \%$ であった。

副作用として2 例に急性精单上体炎が見られたが，重 篤なものはなかった。また，術後一過性の尿閉が10例に 見ら机たため力テーテルの再留置を行っている。図4は， 1 症例の術前術後の経直腸的超音波断層像㧍よび逆行性 尿道造影であるが，前立腺の縮小上尿道の開大が認めら れる。

\section{IV. 考 察}

レーザーを利用した前立腺肥大症の治療は非観血的治 療と TUR-P との中間に位置するとものとして考えら れ， 2 年前より注目を集めはじめるようになった。 米国 IntraSonix 社が開発した TULIP（Transurethral Ultrasound-guided Laser-Induced Prostatectomy) ${ }^{5) 6)}$ と呼ばれるシステムは，7.5MHz， 90 度セクター方式の超音波断層装置にバルーンとレー 


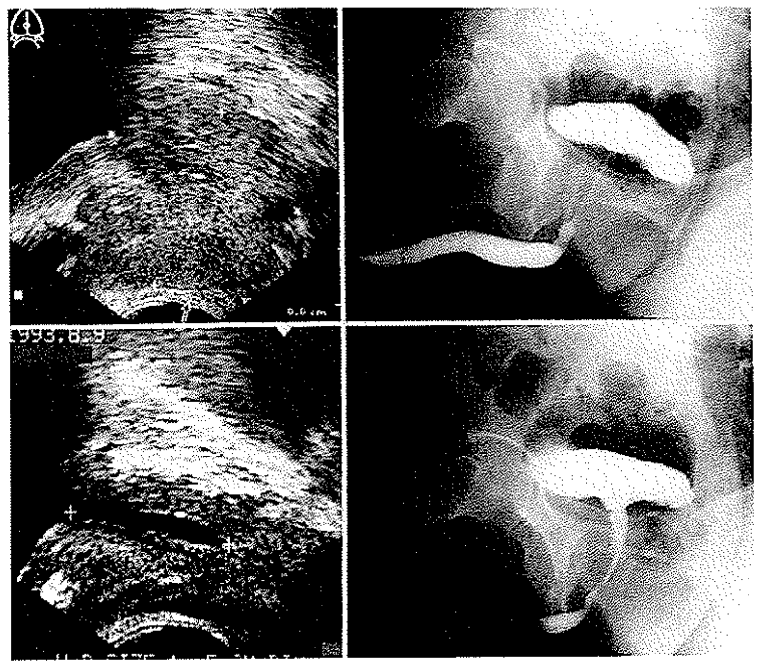

図 4 術前およひ術後 8 週の経直腸的超音波断層像と 逆行性尿道像影

（上段術前，下段術後 8 週）

ザーファイバーを組み込んだものである。経尿道的にプ ローブを挿入し，バルーンを蒸留水で 2 気圧で膨らませ， 前立腺との一定距離を保ち，プローブを前立腺部尿道に 固定後，超音波ガイド下にレーザー照射し，前立腺組織 を出血させることなく凝固壊死させるものである。100 ワットのNd：YAGレーザーがシリコンファイバーを 通じて20Frの尿道プローブの先端でマイクロプリズム を使って90度方向を変え，バルーン内を通過して照射さ れる。照射は非接触照射のため，照射部位には凝固壊死 を生じる。

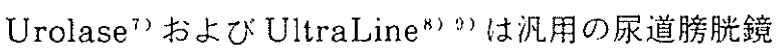
のプローブ用チャンネルから聥入して，前立腺部尿道を 観察しながら $\mathrm{He}$ - Neレーザーによるパイロットビー ムで照射部位を正確に決定し照射することができる。 Urolase ではプローブ先端の金メッキ加工さ狆たステ ンレス製のリフレクターによってレーザー光は90度方向 を变えて前立腺を照射する。照射の際にはファイバーと 前立腺組織間に約 $1 \mathrm{~mm}$ 程の距離を保持する必要がある (非接触照射：凝固中心) ${ }^{7}$ 。

一方, UltraLine では石英ファイバーの先端をカッ トし，プリズム効果によってレーザー光は80度方向を変 えて前立腺を照射する。ファイバーは前立腺組織に対し， 接触あるいは非接触で照射が可能である。

SLT 社の Prostalase はレーザーを使用した前立腺 治療であるが，Nd：YAGレーザーのエネルギーで前 立腺を加温する温熱治療である。また，SLT 社では $\mathrm{Nd}$ : YAG のファイバー先端にサファイヤチップを装 着させ前立腺を直接切開する方法も行っている。

レーザー熱エネルギーの大きさによって組織の変化は
大きく異なり，エネルギーが低い場合には，白色変性を 来たし凝固壊死のみとなる。エネルギ一が高い場合には， 照射部位からバブルが急速に発生して前立腺組織に嘪火 口状のクレーターが生じていく。こ扎は, Nd：YAG レーザーによる蒸散作用であるが，このレーザーの熱エ ネルギーを高くするには，a）レーザー発生装置の出力 を上げるか，b）プローブと前立腺組織との距離を短く するかであるが, UltraLine では完全に接触させて照 射（Free Beam Contact Irradiation）することが可 能であり，50ワットの出力でも充分な点散効果が得ら机 る。Non-Contact Irradiationでのレーザー照射は凝 固が中心よなる。当教室では過去に200例余の膀胱腫瘍 に対し, Contactあるいは Non-Contact Irradiation にて TULS-BT (Transurethral Laser Surgery of

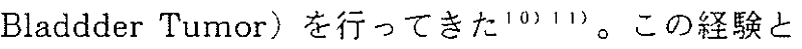
従来より行っている電気メスを用いた TUR-P の経験 を踏まえて，主にContact Irradiationによる蒸散作 用で治療を実施している。

一般に，レーザ一照射により物体の温度は上昇し，物 質の蒸発（気化）により照射部位から気化熱を奪い，蛋 白質の变性上組織の凝固老起こす。さらに, 周围の酸素 による炭化水菜の酸化 (燃焼) が生じ，これらの局所の 温度上昇は熱伝導によって広がっていく。つまり、レー ザーの照射そのものは極めて微少な部分に作用するが， 熱伝等により作用はより広範囲に及ぶは。このことか らも明らかなように，前立線部尿道のレーザー照射部位 は蒸散され，その周囲は遅発性に凝固壊死亡なり，時間 の経過上ともに凝固壊死組織が脱落し，平滑な切除面上 大きな空洞が形成されていく。

Johnson らは,レーザー照射後数時間内に前立線組 織の液状变化が進行し, 凝固壊死組織の脱落が広範囲に わたり始まると述べているは 。

また，わ扎われの実験結果では，50ワット，60秒 (3000ジュール) で1ケ所のSPOT照射を行った場合 に12m以上のクレーターを形成し穿孔を起こしていた。 この結果からも1簓所に高いエネルギーを用いることは 危険であり，SPOT 照射とともにRUNNIG 照射を併 用した方が有意義であると考えられる。

これまでの非観血的前立腺治療はその効果においては 必ずしも充分とはいえず，少なくともTUR-Pにとっ て変わるものは出現しなかった。しかし，前立腺レーザー 手術は徒来の TUR-P のテクニックを基礎とした観血 的手術にもかかわらず，出血を見ることは極めて少ない。 その効果においては確実に前立腺部尿道の閉塞を除去し， TUR - Pに取って変わりうる治療法であるといえよう。 
前立腺肥大症は良性疾患であるため前立腺癌とは異なり， 病理学的所見より症候学的所見が重要視される。徒って, 前立腺肥大症の治療は快適な日常生活を過ごせるように 排尿障害の改善をはかればよい。前立腺レーザー手術は， 今㣪治療経験を積むにつ机て，さらに良いQOLが得ら れることが期待される。

\section{V. 結 論}

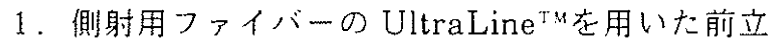
腺レーザー手術を32例の前立腺肥大症患者に行い，自賞 的症状および他党的所見の变化より，その効果を評俩し た。

2. 自覚的症状に関してはAUA-PSSを用い術前掞 よび術後 8 週の变化を記載した。その結果, 治療効果を 認めたのは26例 $(81.3 \%)$ であった。

3. 他當的所見に関しては最大尿流率 - 残尿量・前立 腺推定容積の術前および術後 8 週の变化を用いた。各々 の治療効果は順に24例 $(75.0 \%) ， 28$ 例 $(87.5 \%) ， 31$ 例 (96. 9\%) であった。

4，前立腺レーザー手術による副作用として，2例の 急性精单上体炎と10例の一過性尿閉を経験したが重篤な ものはなかった。

5. 前立腺レーザー手術は新しい前立腺肥大症の手術 として今後期待される治療法である。

\section{文 献}

1）岡田清己, 吉田利夫，遠藤真琴，青木韭ほか：前立 腺肥大症に対寸る経直腸的温熱療法の意義。日泌尿 会誌, $82: 455-461,1991$

2 ) Satoh. Y. , Rin. m. . Yoshida. T. , and Nogaki, $J$, et al : Clinical experience of transrectal hyperthermia for benign prostatic hyperplasia. Jpn. J. Endurol. ESWL, $4: 222,1991$

3 ) Lepor, H. , Sypherd, D. , Machi, G. , and Derus, J. : Ramdomized double-blind study comparing the effectiveness of balloon dilation of the prostate and cystoscopy for treatment of symptomatic benign prostatic hyperplasia. J. Urol, , $147: 639-644,1992$

4) Fabian, K. M. : Der inter-prostatische" Patielle Katheter" (Urological Spirale). Urology, $19: 236-238,1980$

$5)$ Roth, R. A. and Aretz, H. T. : Transurethral ultrasound-guided laser-induced prostatectomy (TULIP procedure) : a canine prostate feasibility study. J. Urol. , 146 : $1128 \cdot 1135,1991$

6) 本間元夫, 高橋悟, 䉴和田滋, 阿曾佳郎：前立腺肥 大症に対する経尿道的超音波ガイド下レーザー前立 腺切除術（TULIP）の治療成績，泌尿外，6：97106, 1993

7 ) 内田䅱昭, 原野裕司, 須山一穂, 西村清志, ほか：

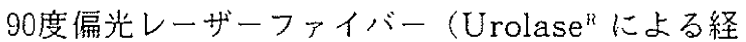
尿道的前立腺切除術 (VLAP) の治療成績. 泌尿 外, $6: 771-781,1993$

8) 野垣諆二, 青木豐, 佐藤安男, 周田清己：前立腺肥 大症の治療の最新動向。温熱療法からレーザ一療法 まで，新医療，:114-117，1993

9）田崎窅，出口修厷，中川健，宮地采典：側射レーザ 一前立腺切除術之経尿道的前立腺切除術の比較検討。 臨泌, 48：228-232, 1994

10) Okada, K. , Asaoka, H. Amagai, T., Onoe, Y. et al : Transurethral Neodymium : YAG laser surgery for bladder tumors. Urology. $20: 404-407,1982$

11) Okada, K. , Nogaki, J. , Saitoh, T. , Kawazoe, $\mathrm{K}$. et al : Balloon Cystoscopy with Neodymium : YAG Laser. J. Urol, , 148 : 285-288, 1992

12）菊地真，新井恒霝：レーザ一光の生体への作用：熱 的作用を中心とした生体作用，癌よレーザ一，図説 臨床癌シリーズ．５：32-39，1986

13) Johson, D. E. , Prince, R. E. and Cromeens, D. M. : Pathologic changes occurring in the prostate following transurethral laser prostatectomy. Laser Surg. Med, , 12 : 254263,1992 